An Adudres:

Ox

\section{SIR THOMAS BROWNE.}

Delivered at the Physical Society, Guy's Hospital, October 12th.

BY WILLIAM OSLER, M D., F.R.S., Regins Professor of Medicine, Oxford.

As a boy it was my good fortune to come under the influence of a parish priest of the Gilbert White type, who followed the seasons of Nature no less ardently than those of the Church, and whose excursions into sclence had brought him into con. tact with physic and physicians. Father Johnson, as his friends loved to call him, founder and Warden of the Trinity College School near Toronto, illustrated that angelical conjunction (to use Cotton Mather's words) of medicine and divinity more common in the sirteenth and seventeenth centuries than in the nineteenth. An earnest student of Sir Thomas Browne, particularly of the Religio Medici, he often read to us extracts in illustration of the beauty of the English language, or he would entertain us with some of the author's quaint conceits, such as the man without a navel (Adam), or that woman was the rib and crooked piece of man. The copy which I hold in my hand (J. T. Fields's edition of 1862), my companion ever since my schooldays, is the most precions book in my library. I mention these circumstances in extenuation of an enthusiasm which has enabled me to make this almost complete collection of the editions of his works I show you this evening, knowing full well the compassionate feeling with which the bibliomaniac is regarded by his saner colleagues.

\section{Tra Max.}

The Little Thomas was happy in his entrance upon the stage, October 19th, 1605. Among multiplied acknowledgements, he could lift up one hand to Heaven (as he saps) that he was born of honest parents, "that modesty, humility, patience, and veracity lay in the same egg, and came into the world "with him. OI his father, a London merchant, but little is known. There is at Devonshire House a family picture which shows him to have been a man of fine presence, looking not unworthy of the future philosopher, a child of 3 or 4 years, seated on his mother's knee. She married a second time, Sir Thomas Dutton, a man of wealth and position, who gave his stepson every advantage of education and travel. We lack accurate information of the early years-of the school days at Winchester, of his life at Broadgate Hall, now Pembroke College, Oxfurd, and of the influences which induced him to study medicine. Possibly he got his inspirs. tion from the Regius Professor of Medicine, the elder Clayton, the Master of Broadgate $\mathrm{H}_{\mathrm{all}}$ and afterwards of Pembroke College. That be was a distinguished undergraduate is shown in his selection at the end of the first year in resi. dence to deliver an oration at the opening of Pembroke Cullege. Possibly between the years 1626, when he took the B.A., and 1629 , when he commenced M.A., he may have been engaged in the stady of medicine ; but Mr. Charles Williams, of Norwich, who is perhaps more familiar than any one living with the history of our author, does not think it likely that he began until he went abroad. In these years he could at least have "entered upon the physic line" and could have proceeded to the M B. He was too early to participate in the revival of science in Oxford, but even after that had occurred Bydenham flung the cruel reproach at his Alma Mater that he would as soon send a man to her to learn shoemaking as practical phystc. It was possible, of course. to pick up a little knowledge of medicine from the loca practitioners and from the Pnysic Garden, together with the lectures of the Regius Professor, who, as far as we know, had not at any rate the awkward failing of his more distinguished son, who could not look upon blood without fainting, and in conequence had to hand over his anatomy lectures to a deputy.

Ulayton's studies and work would naturally be of a somewhat mixed chiracter, and at that period even many of those whose chief business was. theology were interested in natural philosophy, of which medicine formed an important part. Burton refers to an address delivered about this time by Clayton dealing with the mutual relations of mind and body. The Anatomy of Melancholy, which appeared in 1621, must have proved a stimulating bonne bouche for the Oxford. men of the day, and I like to think of the eagerness with which so ardent a student as Browne of Pembroke would have pounced on the second and enlarged edition which appeared in 1624. He may, indeed, have been a friend of Burton, or he may have formed one of a group of undergraduates to watch Democritus Junior leaning over the bridge and laughing at the bargees as they swore at each other. It is stated, I know not with what authority, that Browne practised in Oxford for a time.

After a visit to Ireland with his stepfather he took the grand tour-France, Italy, and Holland-spending two years in study. Of his Continental trip our knowledge is very. meagre. He went to Montpellier, still famous, but failing, where he probably listened to the teaching of Riviere whose "Praxis" was for years the leading textbook in Europethence to Padua, where he must have heard the celebrated Sanctorius of the Medicina Statica - then on to Leyden, just rising into prominence, where it is said he took his doctor's degrte in 1633. Of this, however, there is no certainty. A few years ago I looked through the register of that famous University, but failed to find his name. At the end of two. years' travel he may have had cobwebs in his pocket, and the Leyden degree was expensive, as that quaint old contempcrary of Browne, the Rev. John Ward of Stratford-on.Avon, tells us (Diary) "Mr. Burnet had a letter out of the Low Counties of the charge of a doctor's degree, which is at Leyden about $f_{1} 16$, besides feasting the professors; at Angers in France, not above 69 , and feasting not necessary neither." No doubt he got of the best that there was in the teaching of the day, but from the Religio one learns that the young Englishman got an extraordinary breadth of culture, and a charity not always granted to travellers in his day. Beneath the shell of nationalism he got into the heart of the people among whom he lived, feeling at home everywhere and in any clime. For a Protestant he got a rare charity expressed so. beautifully in the lines: "I can dispense with my hat at the gight of a cross, but scarce with the thought of my Baviour."

He must have made good use of his exceptional opportunities as he was able to boast, in a humble way it is true, that he understood six languages.

In 1634 he settled at Shibden Hall, near Halifax, and here before his thirtieth year, he wrote the Religio Medici, the book by which to-day his memory is kept green among us. In his travels he had doubtless made many observations on men and in his reading had culled many useful memoranda. He makes it quite clear-and is anxious to do so-that the book was written while he was very young. He says: "My life is a miracle of thirty years." "I have not seen one revolution of Saturn." "My pulse hath not beat thirty years." Indeed he seems to have been of Plato's opinion that the pace of life slackens after this date, and there is a note of sadness in his comment, that while the radical humour may contain sufficient oil for seventy, "in some it gives no light past thirty," and he adds that those dying at this age should not complain of immaturity. In the quiet Yorkshire valley, with leisurable hours for his private exercise and satisfaction, the manuscript was completed and "communicated to one it ke came common to many, and at last in 1642 , seven years after its completion. reached the press in a depraved form. In 1637 , at the solicitation of friends he moved to Norwich, with which city. so far as we know, he had not had previous affiliation. At that date the East Anglian capital had not become famous in the annals of medicine. True, she had given Caius to the profession, but he had only practised there for a short time and does not sepm to have had any special influence on her destinies. Sir Thomas Browne may be said to be the first of the long list of worthies who have in the past two and a-half centuries made Norwich famous among the provincial towns of the kingdom. Here for forty five sears he lived the quiet, uneventful life of a student.practitioner, absorbed, like a sensible man, in his family, his friends, his studies and his patients. It is a life of singular happiness to contemplate. In 164I he married Dorothy Mileham, "a lady of such a symmetrical proportion to her worthy husband - that they seemed to come together by a kind of natural magnetism." In the Religio he had said some hard things of the gentle goddess and had expres:ed himself very strungly against Nature's method for the 
propagation of the race. He believed, with Milton, that the world should have been populated "without feminine" and in almost identical words they wish that some way less trivial and vulgar had been found to generate mankind. Dame Dorothy proved a good wife, a fruitful branch, bearing ten children. We have a pleasant picture of her in her letters to her boys and to her daughter-in-law in an orthography suggestive of Pitman's phonetics. She seems to have had in full messure the simple piety and the tender affection mentioned on her monumpnt in St. Peter's Church. The domestic correspondence (Wilkin's edition of the Works) gives interesting glimpses of the family life, the lights and shadows of a cultured English home. The two boys were all that their father could have wished. Edward, the elder, had a distinguished career, following his father's footsteps in the profession and reaching the dignity of the Presidency of the Roygl College of Physicians. Inheriting his fatber's tastes, as the letters between them show, his wide interests in natural history and archaeology are shown in his well-known book Trabks, a copy of which I here show you, and it may interest some of you to see this copy of the Fydriotaphia with his autograph, His san, the "Tommy" of the letters, the delight of his grandfather, also bocame a pbysician, and practised. with his father. He died in 17 ro under rather unfortunate oircumstances, and with him the male line of Sir Thomas ended. Of the younger son we have, in the letters, a charming picture-a brave sailor-lad with many of his father's tastes, who served with great distinetion in the Dutch wars, in whioh he met (it is supposed) a sailer's death. The eldest daughter married Henry Fairfax, and through their deugther, who married the Earl of Buchers, there are to-dar among the Buchans and Erokines the only existing representatives of Xir Thomas.

The waves and storms of the Civil War searcely reached the quiet Norwich home: He was a staunch Rogalist, and his neme oecurs among the citizens who' in 1643 refused to contribute to a fund for the recaptuie of the town of Newcastle. It is astonishing how few references occur in his writings to the national troubles, which must have tried his heart sorely. Only in the preface to the Religio does he give vent to his feelings, lamenting not only the univereal tpranny of the Prese, but the defatiation of the name of His Mujesty, the depravation of Parliament, and the writings of both "depravedly, anticipatively; counterfeitedly im printied." In one of the letters he speals 8 of the execution of Charles I as " horrid murther," and in another hecalls Cromwell a usurper. In civil wars physicians of all men suffer least, as the services of able men are needed by both parties, and time and agein it has happened that an even-balanced soul, such a our anthor, has passed quietly through terrible trials, doing the day's work with closed lips. Corresponding with the most active decades of his life, in which his three important works were issued, one might have expected to find in them reterence to the Civil War, or, at least, echoes of the great change wrought by the Commonwealth, but, like Fox, in whose writings the same silence has been noticed, whaterer miy have been his feelings he preserved a discreet silence. His own rule of life, no doubt, is expreseed in the advice to his son: "Times look troublesome, but you have an honest and peaceable profession which may employ you, and discretion to guide your words and actions."

Basg, with his professional work, interested in natara histary, in archaeology, and in literature, with a wide circle of scientitic friends and correspondents, the glimpses of his life, which we have from the letters, are gingularly attractive. Hé adopted an admirable plan in the education of his children, sending them abroad, and urging them to form early babits of independence. His younger boy, Thomas, he sent at the age of $i_{4}$ to France, alone, and he remarks in one of his letters to him: "He that hath learnt not in France travelleth in vain." Everywhere in the correspondence with his children there is evidence of $\mathrm{g}$ rod, practical sense. He tells one of the boys to" cast off pulor rusticu", and to have a handgome garb of his body." Even the daughters were taken to France. Through the kindness of Mr. Williams I am able to show you a picture of his house, which, unfortunately, was torn down some years ago, but the handsome mantelpiece has beeu preserved (Fig. I).

An interesting contemporary account has been left by Evelyn, who paid a visit to sir Thomas in 1673 . He says “. ... the whole house being a paradise and a cabinet 0 rarities, and that of the best collections, especially medails, books, plants, and natural things. Amongst other curiosities Sir Thomas had a collection of the eggs of all the foule and birds he could procure, that country, espeeially the promintory of Norfolck, being frequented, as he said, by several kinds which seldom or never go further into the land, as cranes, storkes, eagles, and a variety of other foule."

After Dr. Edward Browne was established in Landon the letters show the keen interest Sir Thomas took in the scientifin: work of the day. Writing of his son's lecture on anatomy at the Chirurgical Hall, he warns him that he would have more spectators than anditors, and after that tirst day, as the lecture was in Latin. "very many will not be earnest to come here-after." He evidently takes the greatest interest in his son's progress, and constantly gives him suggestions with reference to new points that are coming up in the literature. Here and there are references to important medical cases, and comments upon modes of treatment. It is interesting to note the prevalence of agues, ever of the severe haemorxhagic types, and his nee of Peruvian bark. In one of the letters a rema! buble case of pnenmothorax is described: "A young woman who had a julking and fluctuation in her chest so that it might be heard by standersby." Evidently he had a large and ortenaive practice in the Easten Qonntice. and there are numerous referenees to the local pbysicians. There is a poem extolling his akill in the despaired-of case of Mre. E. B., three or four of the lines of which are worth quoting

He came, saw, eur'd! Could Caesar's self do more ;

Gajen, Heppocraten, London' foux score

Of ffamous Calledge... had these heard him read.

His lecture on this Skeliton, half dead

And seen his modest eje search every part,

Judging, not seelng.

The correspondence with his son is kept up to the time of his death. Onir nart of the letters appears in Wilkin's Eife, and there are many extant wortby of puhlication.

In 167 t he was knighted by Charles $\mathrm{II}$ In 16\%4 he was made an honorary Fellow of the Royal College of Physicians, with which, through his son, he hadclose affiliations. His namedoes notappear in the roll of the Rogal Society, with the house. spirits and objects of which he must have had the warmes sympathy. He was in correspondence with many of the leading men of the da, - Evelyn, (trew, Elias Ashmole, Dugdale, Pdston, Aubrey, and otwery. The letters deal with a remark able variety of subj $\theta$ ts -natural history, botany, chemistry, magic and archaeology, etc. The Freudodoxia Epidemiea (1646) extended his reputation among all classes and belped to briug him into close relationship with the virtuosi of the pariod, There is in the Bodleian a delightful letter from Mr. Henry Bates, a wit of the court, a few extracts from which will give you an idea of the extravagant admiration excited by his writings: "Sir,-Amongst those great and due acknow ledgements this horizon owes you for imparting your sublime solid phansie to them in that incomparable piece of invention and judgment, $R$ M. gives mee leave, sir, here at last to tender my share, which I wish I could make proportionable th the value I deservedly sett upon it, for truly, sir, ever since I had the happiness to $\mathrm{knnw}$ your religion I have religiously honoured you; hag'd your Minerva in my bosome and voted it my vade mecum." .. " "I am of that opinion still, that next the Legenda Dei. it is the master piece of Christendome; and thougn I have met sometimes with some omnes sic ego vero non sic men prejudicating pates, who bogled at shadowes in 't and carpt at atoms, and have 80 strappadoed me into impatience with their senseless censures, yet this still satisfied my zeal toward it, when I found non intellgunt was the nurse of 
theire vituperant, and they onely stumbled for want of a lav thorne.'

While interested actively in medicine, he does not seem to have been on intimate terms with his great contemporariesHarvay, Bydenham, or Glisson-though he mentions them, and alway s with respect. He:was a pradent, prosperous man generous to his children and to his friends. He subscribed iberally to toe rebuilding of the Library of Trinity College, C.mbridge, and to the repairs at Christ Church, Oxford. A life placid, aneventful, and easy, without stress or strain happy in his friends, his family, and his work, he expressed in It that harmony of the inner and of the outer man which it is the aim of all true philosophy to attain, and which he inculcated 80 nobly and in such noble words in the Religio Medidi and in the Christian Morals.

A description of $h ı m$ given $b y$ his friend, the Rev. John Whitefoot, is worth quoting: "He was never seen to be tran-ported with mirin or dejected with sadness; always cherfal hut rarely merry, at any sensible rate; seldom heard to break a just, and when he did he would be apt to blush at the levity of it. His gravity was natural, without affectation."

The end came unexpetedly in his $77_{\text {th }}$ year, after a sharp attack of colic, on his birthday, October 5 th, 1682-a curiou coincidence of which he speaks in the Letter to a Friend: "But in yersons who outlive many years, and when there are no less than 365 days to determine their lives every yearthat the first day should make the last, that the tail of the snake should return into its mouth precisely at that time, and they should wind ap upon the day of their nativity-ls, indeed, a remarkable coincidence, wh i ch, though astrology hath taken witty pains to solve, get hath it been very wary in making predictions of it."

There are three good por traits of Sir Thomas-one in the Colluge of Physicians, London, which is the best known and has been often reproduced, and is the frontis piece of Greenhill's edition a second is in the Bodleian, and has frequently been reproduced; the third is in the vestry of St. Peter's Mancroft, Norwich. * Through the kindness of Mr. Charles Williams, I am able to show you this beautiful photograph of it. In many ways it is the most pleasing of the three, and he looks in it a younger man, closer to the titious edition.

days of the Religio. There is a fourth picture, the frontispiece to the tifth edition the Pseudodoxia, but it is 80 unlike the others that I doubt very much if it could have been Sir Thomas. If it 'was, he must have suffered from the artist, as did Milion, whose picture in the frontispiece to the Potms, 1645, is a base caricatuxe, but Browne has not had the satisfaction of Milton's joke and happs revenge.

$$
\text { II.-THE Book. }
$$

As a book the Religio Medici has had an interesting history Written at "leisurable hours and for his private exercise and satisfaction," it circulated in manuscript among friends, "and was by transcription successively corrupted, until it arrived in a most depraved copy at the press." Two surreptitious editions were issued by Andrew Orooke In 1642 (Fig. 2), both in tamall octavo, with an engraved frontispiece by Marshall repre senting a man falling from a rock (the earth) into the sea of eternlty, but caught by a hand issuing from the clouds, under which is the legend "A Coelo Salus." Johnson suggests that the author may not have been ignorant of Orooke's design, but was very willing to let a tentative edition be lasuedstratagem by which an author panting for fame, and $\bar{y}$ et afraid of seeming to challenge it, may at once gratify his vanity and preserve the appearance of modesty."

There ars at Jeast five manuscripts of the Religio in

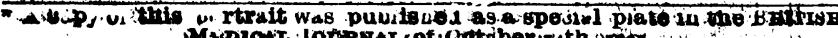

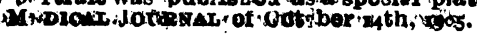

existence, all presenting minor differences, whioh bear out the author's contention that by transcription they had become depraved. Had he been party to an innocent fraud he would scarcely have allowed Crooke to issue within a year a second imperiect 4 dition - not simply a second impression, as the two differ in the size and number of the pages, and present also minor differences in the text. The authorized edition appeared in the following year by the same publisher and with the same frontispiece, with the following words at the foot of the plate: "I true and full copy of that which was most imperfectly and eurreptitiously printed before under the name of Religio Medici" (Fig. 3). It was issued anongmonsly, with a preface, signed ". $A$. B." : "To such as have or shall perase the otservations apon a former corrupt cops of this Booke." A curious incident here links together two men, types of the intellectasl movement of their generstion-both students, both mystics-the one a quiet observer of nature, an antiquary and a physician; the other a restless spirit, \& bold bucceneer, a politician, a philosopher, and an amateur physician. Sir Kenelm Digby, committed to Winchester Huuse by the Parliamentarians had heard favourably from the Earl of Durset of the Religio Medici. Though late in the day, "the magnetic motion, as he ays, was imputience to have the booke in his hands," so be sent at once to St. Paul's churchyard for it. He was in hed when it came. "This good natur'd creature I could tasily perswade to be my bedfellow and to wake me as long as I had any edge to entertain myselfe with the delights I sucked in from so noble a conversation. And truly I closed not my eyes till I had enricht myselfe. with (or at least exactly survesed) all the treasures that are lapt up in the folds of those new sheets." Sir Kenelm holds the record for reading in bed; not nnly did he read the Religio through, but he wrote "Ooservations" upon it the same night in the form of a letter to his friend, which extends to three-fourths of the rize of the Religio itself. As Johnson remarks, he "returned his judgement of it not in the form of a letter but of a book." He dates it at the end "the 22nd. (I think I may say the 23 rd, for 1 am sure it is morning and I hink it is day) of December, 1642." Johnson says that its principal olaim toadmiration

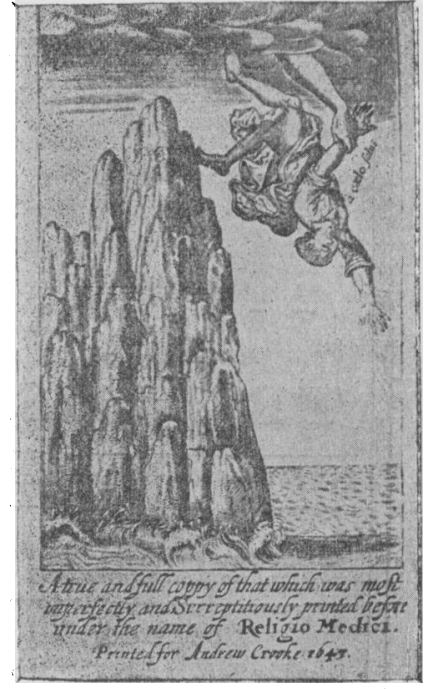

Fig. 3.-Frontispiece of authorized edition. that it was written within twenty-fourihours, of whioh part was apent in procuring Brownels book and part in reading sit. Sir Kenelm was a remal kable man, but in connexion with his statements it maj be well to remember the seputation he had among his contemporaries, Stubbes calling him "the Pliny of our age for lying." However this may. be, his criticisms of the work are exceedingly interesting ana often just. This little booklet of Sir Kenelm has floated down the stream of literature, reappearing at intervals attached to editions of the Religio, while his weightier tomes are deep in the ooze at the bottom.

The Religio Medica became popular with remarkable rapidity. As Johnson remarks, "It excited attention by the novelty of paradoxes, the dignity of sentiment, the quick succession of images, the multitude of abstrusive allusions, subtility of disquisition, and the strength of language." A Cambridge student-Merryweather-travelling in Europe, translated it into Latin, and it was published in 1644 by Hackius at Leyden in a very neat volume. A second impression appeared in the same year, and also 8 Paris edition-a reprint of the Leyden. The Continental soholars were a good deal puzzled and not altogether certain of the orthodoxy of the work. Merrymeather, in a very interesting letter ( 1649 ) sags that he had some difficulty in getting a printer at Leyden. Salmasing, to whom Haye, a book merchent, took it for approbation, said ' that there in it many thing well said, but that it contained also many 
exorbitant conceptions in religion and would probably find much frowning entertainment, especially amongst the ministers." Two other printers alsu refused it. The most interesting Continental criticism is by that distinguished member of our profession, Gay Patin, professor in the Paris Faculty of Medicine. In a letter to Charles Sp in of Lyons, dated Paris, October 218t, 1644, he mentions having recelved a little book called the Religio Medici, written by an Englishman, "a very mystical book contuining strange and ravishing thoughts " In a letter, dated 1645, he says the book is in high credit here; the author has wit, and there are abundance of fine things in the book. He is a humorist whose thoughts are very agreeable, but who, in my opinion, is to seek for a master in religion may in the end perhaps find none. Patin thought the author in a parlous state, and as he was still alive he might grow worse as well as better. Evidently the work became a favourite one with Patin, as in letters of $1650-1653$ 657 he refers to it again in different editions. It is remarkable that he nowhere mentions the author by name, but subsequently when Edward Browne was a student in Paris Patin sends kindly greetings to his father.

Much discussion occurred on the Continent as to the orthodoxy of the Religio. It is no slight compliment to the author that he ohould have been by one claimed as a Catholic, by another dennunced as an Atheist, while a member of the Society of Friends $\mathrm{saw}$ in him a likely convert. The book was placed on the Index. In England, with the exception of D i g b g's Observations, there were no adverse criticisms of any note.

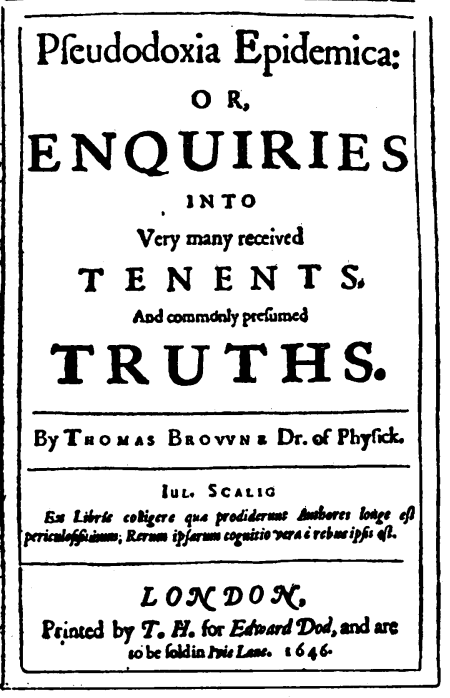

Tig. 4. -Title-page of the Pseudodoxia.
Alezander Ross, that interesting old. Southampton schoolmaster, who seems always to have been ready for an intellectual tilt, wrote a criticism entitled Medicus Medicatus, or the Physician's Religion cured by a Lenitive or Gentle Potion.

In England there were two reprints in 1645 , and it appeared again in the years 1656, 1659. 1669, 1672 an'1 in 1682 , the year of Browne's death. As you may see in these examples, all have the same frontispiece and are, with slight variations, reprints of the 1643 edition. The work also began to be reprinted with the Preudo doxia Epidemica (third edition, 1659 ). The

Latin editions followed each other rapidly. As I mentioned, it first appeared at Leyden in 1644, and was reprinted the same year there and in Paris; then in 1650 in Leyden again, in 1652 in Strassburg, and in the same place in 1665 and 1667. Tne most important of these editions was that of Strassburg, 1652, with elaborate notes by Moltkins, of which Gay Patin speaks as "miserable examples of pedantry," and indeed stignatizes the commentator as a fool. 'The Dutch translation appeared in 1655 and a French in 1668, so that altogether during the author's lifetime there were at least twi nty editions of the work.

In the seventeenth century there were in all twenty-two editions. In the eighteenth century there were four English editions, one Latin, and one German. Then a long interval of seventy-eeven years elapsed, until in 1831 Thomas Chapman, a Jcung Ereter College man, edited this neat little volume a very precious book, as. it is fall of marginal notes by r. T. Coleridge, who was one of the earliest and most critical among the students of Sir Thomas. In the same year the first American edition was published, edited by the Rev. Alexander Young, of Boston. In 1838 appeared an excellent edition by. J. A. St. John, "traveller, linguist, author, and editor," and in 1844 Lnngman's edition by John Peace, the librarian of the City Librarg, Bristol. This edition was republished in America by the house of Lee and Blanchard, ${ }^{2}$ Phi'adeluhia, the only occasion, I belipve, on which the Religio has been issued by a firm of medical pablishess. In
1845 appeared Pickering's beautiful edition, edited, with many orivinal notes, by the Kev, Henry Gardiner, in many ways the most choice of nineteenth.century issues. In 1862 James Tick nor Fields, the well. known Boston scholar and publisher, brought out a very handsome edition, of which, for the first time in the history of the book an edition de luxe appeared in this large paper ropy. In 1869 appeartd Sampson Low and Co.'s edition by Willis Bund; und in 1878 Rivington's edition edited by $W$. P. Smith. Then in 1881 appeared what must always remain the standard edition edited by Dr. Greenhill for the Golden Treasury Spries, and reprinted successively by Macmillan and Co. To his tark Dr. Greenhill brought not only a genuine love of Sir Thomas Browne, but the accuracy of an earnest, painstaking scholar. Since that date a dozen or more editions have appeared, of which I may mention the excellent one by Dr. Lloyd Robrrts, of Manchester. I may finish i his dry summary by asking you to contrast this little parchment-covered surreptitions edition of 1642 with the sumptuous folio of the Vale Press. In all, including those which have appeared with the collected works, there have been about filty-five editions. Browne atates that the work had also been translated into High Dutch and into Italian, but I can find no rec ird of these editions, nor of a German translation, 1680, mentioned by Watt.

Time will allow only a brief reference to his other writings. Pseudodoxia Epidemica ; or, Inquiries into very many received Tenet and commonly-presumed Truths, appeared in 1846 in this small folio (Fig. 4). In + xtent this is by far the most pretentious of Browne's works. It f.,rms an extraordinary collection of old wives' fables and popular beliefs in every department of human knowlerge, dealt with from the stand point of the acience of that day. In a way it is a strong protest against general credulity and inexactness of statement, and a plea for greater accuracy in the observation of facts and in the recording of them. Walter Pater has drawn attention to the striking resem. blance between Browne's chapter on the Sourcer of Error and Bacnn's doctrine of the Idola-shams which men fall down and worship. He discusses cleverly the use of doubts ; but, as Pater remark8, "Browne was himself a rather lively example of entertainments of the Idols of the Cave-Itola Specus-and, like Boyle,
HYDRIOTAPHIA URN E-BURIALL, OR,

A Difcourfe of the Sepulchral Urnes laxely found in

N OR FOLK. Togetber with

The Garden of $C Y R \cup S$, OR THE

Quincunciall, Lozenge, or Net-work Plantations of the Ancienta, Arrificially, Naturally, Mystically Confidered.

With Suadry Obfervations

By Tbomes Browom D.of Phyfick. $10 \pi D O N$

Prineed lor Hen. Brame at the Signe of the

Iig. 5.-Title-page of the Urw-Burial. Con in Ivy-lase. 2698 .

not quite free himself from the shackles of alchemy and a hankering for the philosopher's ston+8." The work was very popular, and extended the reputation of the author very widely. Indeed in 1646 Browne was not known at large as the author of the Religio, as his name had not appeared on the title-page of any edition issued at that date. It was reprinted in these editions $a$ hich I show $J$ ou, and it appeared in French both in France and in Holland.

Equalling in popularity among certain people the Religio, certainly n+xt to it in importance, is the remarkable essay known as Hydriotavhia-Urne-Burial; or, $A$ Discourse of the Sepulchrale Urnes lately Jound in Norfolk (1658). Printed with it is The Garden of Cyrus, a leurned discourse on gardens of al) forms in all ages. Natural'y when an unusual number of funeral urns were found at Walsingham they were brought to the notice of Browne, the leading ant quary of the county. Instead of writing a learned disquisition upon their date-ke thought them Roman, they were in reality Saron-with accurate measurements and a catalogue of the bones, he touches upon the whole incident very lightly, but, using it as a text, breaks out in to a noble and inspiring prose poem a meditation upon mortality and the last sad rites of all nations in all times, with learned comments on modes of sepulchre, illustrated with much antiquarian and historical lore. Running through the work is an appropriate note of malancholy at the sad fate which awaits the great majority of us, npon whom the iniquity of obliviou must blindly scatter 
her poppy. "The greater part must be content to be as though they had not been, to be found in the register of God, not in the record of man."

Nowhere in his writings does the prose flow with a more majestic roll. Take, for example, this one thought: "If the nearness of our last necessity brought a nearer conformity unto it, there were a happiness in houry hairs and no calamity in half senses. Bat the long habit of living indisposeth us for dying, when avarice makes us the sport of death, when even David grew politically cruel, and Solomon could hardly be seid to be the wisest of men. Bat many are too early old and before the days of age. Adversity stretcheth our days, misery makes Alcemena's nights, and time hath no wings unto. it."

Closely connected in sentiment with the Urm-Burial is this thin folio pamphlet-the rarest of all Browne's works, printed posthumonsly in 1698-A Letter to a Friend on the Occasion of the Death of his Intimate Friend (Fig. 6). It is a splendid dissertation on death and modes of dging, and is a unique study of the slow progress to the grave of a consumptive. It is written in his most picturesque and characteristic vein, with such a charm of diction that some critics have given it the place of honour among his works. Pater, in most enthnsiastic terms, apeaks of it with the Urn-Burial as "the best justification of Browne's literary reputation."

The tender sympathy with the poor relics of humanity which Browne expresses so beautifully in these two meditations has not been meted to his own. "Who knows the fate of his bones or how often he is to be buried ?" he asks. In 1840 , while workmen were repairing the chancel of St. Peter Mancroft, the coffin of Sir Thomas was accidentaliy opened, and one of the workmen took the skull, which aiterwards came into the possession of Dr. Edward Lubbock, who denosited it in the Museum of the Norfolk and Norwich Infirmary. When I first saw it there in 1872 there was on it a printed slip with these lines from the $B y d r i o-$ taphia: "To be knaved ont of our graves, to have our skulls made drinking bowls, and our bones turned into pipes, to delight and sport our enemies, are tragical abominations escaped in burning burials." The skull has been carefully described by Mr. Charles Williams, to whom I am indeoted for these photographs which I here show you.

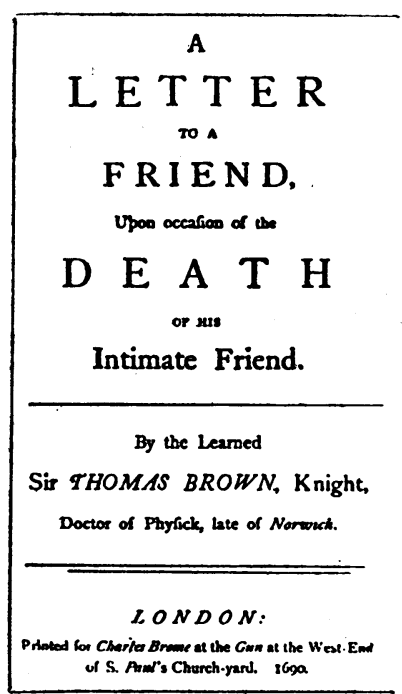

Fig. 6.-Title-page of $\Delta$ Letter to a Friend.
In addition to the "Letter to a Friend," there are three posthumous works, Certain Miscellany Tracts (1684), edited by Archbishop Tenison, an $\downarrow$ Posthumous Works, 1712, containing chiefly papers of antiquarian interest. In the same year, 1712, appeared the Christian Morals, edited by Archdeacon Jeffrey of Norwich, from a manuscript found among Browne's papers. Probably a work of his later life, it forms a series of ethical fragments in a rich and stately prose which, in places, presents a striking parallelism to paseages in the Hebrew poetry. The work is usually printed with the Religio, to which in reality it forms a supplement.

Of the collected editions of Browne's works, this, a fine folio, appeared in 1686 . In 1836 , Simon Wilkin, himself a Norwich man, edited the works with the devotion of an ardent lover of his old townsman, and with the critical accuracy of a scholar. All students of Sir Thomas remain under a lasting debt to Mr. Wilkin, and it is pleasant to know, through the kindness of his daughter-in-law, Mrs. Wilkin, of Sidmouth, a Sir Thomas Browne Library has been founded in connexion with the Norwich Museum, in which Mr. Simon Wilkin's collections have been placed. A three-volume edition of the works is in course of publication by Grant Richards, 1904-5.

III.-Comments.

In this country from Johnson to Walter Pater critics have put on record their estmate of Browne and of his place in literature, and among whom for keenness of appreciation Pater takes the first rank. Lamb and Coleridge dearly loved the old Norwich physician, in whom they found a kindred spirit. In America the New Eugland writers. Ticknor Fields, Holmes, and Lowell were ardent students of his workg. Lowell in particulal is fond of apt quotations from him, and in one place speaks of him as "our most imaginative mind since Shakespeare." But no one has put so briefly and so clearly the strong characters of our author as the French critic, Taine: "Let us conceive a kindred spirit to Shaker peare's, a scholar and an observer instead of an actor and a poet, who in place of creating is occupied in comprehending, but who, like Shakespeare, applies himself to living things, penetrates their internal structure, puts himself in communication with their actual lawe, imprints in himself fervently and scrupulously the smallest details of their figure; who at the same time extends his penetrating surmises beyond the region of observation, discerns behind visible phenomens a world obscure yet sublime, and trembles with a kind of veneration before the vast, indistinct, but populous abyss on whose surface our little universe hangs quivering. Sach a one is Sir Thomas Browne, a naturalist, a philosopher, a scholar, a physician, and a moralist, almost the last of the generation which produced Jeremy Taylor and Shakespeare. No thinker bears stronger witness to the wandering and inventive curiousity of the age. No writer has better displayed the brilliant and sombre imagination of the North. No one has spoken with a more eloquent emotion of death, the vast night of forgetfulness, of the all devouring pit of human vanity which tries to create an immortality out of ephemeral glory or sculptured stones. No one has revealed in more glowing and original expressions the poetic sap which flows through all the minds of the age."

The growing pnpularity of Browne's writings testifies to the assured position he holds, if not in the hearts of the many, at least in the hearts of that saving remnant which in each generation hands on the best traditions of our literature. We, as members of his profession, may take a special pride in him. Among physicians, or teachers of physic, there is, perhaps, but one name in the very first rank. Rabelais. stands apart with the kings and queens of literature. Among the princes of the blood there are differences of opinion as to their rank, but Sir Thomas Browne, Holmes, and John Brown of Edinburgb, form a group together high in the circle. Of the three, two were general practitioners; Oliver Wendell Holmes only in the early part of his life, and for forty years a teacher of anatomy; but all three have far closer ties with us than Goldsmith, Smollett, or Keats, whose medical affiliations were titular rathrr than practical.

Burton, Browne, and Faller have much in common-a rare quaintness, a love of odd conceits, and the faculty of apt. illustrations drawn from out-nf-the-way sources. Like Montaigne-Burton even more-Browne's bookishness is of a delightful kind, and yet, as he maintains, his best matter is not picked from the leaves of any author, but bred among the "weeds and tares" of his own brain. In his style there is a lack of what the moderns call technique, but how pleasant it is to follow his thoughts, rippling like a burn, not the stilled. formality of the technical artist in words, the cadencies of whose precise and mechanical expressions pall on the ear.

As has been remarked, the Religio Medici is a tour de force, an attempt to combine daring scepticism with humble faith in the Christian religion. Sir Thomas confesses himself to be "naturally inclined to that which mirguided zeal terms superstition." He " cannot hear the Ave Maria bell without. an elevation." He has no prejudices in religion, but sab-. scribes himself a loyal son of the Church of England. In clear Janguage he says, "In brief, where the Scripture is silent the Church is my text; where that speaks it is but my comment. When there is a joint silence of both, I borrow not the rules of my religion from Rome or Geneva, but from the dictates of my own reason." He is hard on the controversialist in religion, "every man is not a proper champion for truth, nor fit to take up the gauntlet in the cause of verity," etc. While he disclaims. any "taint or tincture" of heresy, he confesses to a number of heretical hopes, $8 \mathrm{such}$ as the ultimate salvation of the race, and prayers for the dead. He freely criticizes certain seeming absurdities in the Bible narrative. His travels have made him cosmopolitan and free from all national prejudices. "I feel not in myself those common antipathies trat I can discover in others, those national repugnancies do not touch me, nor do I behold with pri judice the French, Italian. Spaniard; or Dutch ; but where I find their actions in balance with my countrymen's, I honour, love, and embrace them in the same degree. I was born in the eighth climate, but seem for to be framed and constellated unto all. I am no plant that will not prosper out of a garden; all places, all airs, make unto me one 
country; I am in England, everywhere, and under any meridian." Only the "Ionl multitude" that chnoses by show he holds up to derision as "that numerous piece of monstrosity, which, taken asunder, seem men, and the reasonable creatures of God; but confused together, make but one great beast, and a monstrosity more prodigious than Hydra." He has a quirk sympathy with the sorrows of others, and, though a physician, his prayer is with the husbandman and for healthful seasons. No one has put more beautifully the feeling which each one of us has had at times about patients : "Let me be sick myself, if sometimes the malady of my patient be not a disease unto me; I desire rather to cure his infirmities th tn my own necessities; where I do him no good, methinks it is scarce honest gain; though I confess 'tis but the worthy salary of our well-intended endeavours."

He has seen many countries, and has studied their customs and politics. He is well versed in astronomy and botany. Fe hus run through all systems of philosophy but has found no rest in any. As death gives every fool gratis the knowledge which is won in this life with sweat and vexation, he counts it absurd to take pride in his achievements, though he understands six languages besides the patois of several provinces.

As a scientific man Browne does not take rank with many of his contemporaries. He had a keen power of observation, and in the Pseudodoxic and in his letters there is abundant evidience that he was an able naturalist. He was the first to observe and describe the peculiar substance known as adipo. cere, and there are in places shrewd flashes, anch as the suggestion that the virus of rabies may be mitigated by transmission from one animal to another. We miss in him the clear, dry light of science as revealed in the marvellous works of his contemporary, Harvey. Busy as a practical phystcian, he was an observer, not an experimenter to any extent, though ho umg-s: "Join sense unto reason and experiment unto geeculation, and 80 give life unto embryon truths and verities yet in their chaos." $\mathrm{He}$ had the higheat veneration for Farver. whose work he recognized as epoch making-" his piece, De Circul. Sang., which discovery I prefer to that of Columbus." He recogniz ${ }^{2}$ that in the faculty of observatiion the old Greeks were our masters, and that we must return to their methods if progress were to be made. He had a much clearer idea than had sydenham of the value of anatomy, and tells his young friend, Power of Halifax, to make Autopsia his fidus Achates

That he should have believed in witches, and that he should have given evidence in 1664 whlch helped to condemn two poor momen, is always spoken of as a blot on his character; but 8 man must be judged by his times and his surroundings. While regretting his credulity, we must remember how hard it was in the sixteenth and seventeenth centuries not to believe in witches-how hard, indeed, it should be to-day for any one who b lieves implicitly the 0ld Testament!-and men of the stamp of Reginald Scot and Johannes Wierns, who looked at the question from our point of view, were really anomalies, and their strong presentation of the rational side of the problem had really very little influence on their contemporaries.

For you, young men, the writings of Sir Thomas Browne have a very positive value. The charm of high thoughts clad in beautiful Janguage may win some of you to a love of gond literature; but beyond this is a still greater advantage. Like the Flloughts of Marcus Aurelius and the Enehiridion of Spictetus, the Religio is full of counsels of perfection which appeal to the mind of youth, still plastic and an. hardenea by contact with the world. Carefully studied, from such books come subtle influences which give stability to charaeter and help to give a man a sane outiook on the complex problems of life. Sealed early of this tribe of authors, a student takes with him, as compagnons de voyage, life-Iong fiends whose thoughts become his thoughts and whose ways tecome his ways. Mastery of self, conscientious devotion to dutry, deep human interest in human beings-these best of all lessons you must learn now or never; and these are some of the lessons you may glean from the life and from the lips of Sir Thomas. Browne.

REPRRENCE AND NOTE. 1 Wilkin, vol. I. p. 253.2 They did not issue an edition in 1848, as

A Mrmorial to Oblimr.-A statue of Ollier, the famons surgeon of Lyons, has recently been erected in his native place; Vaus, in the Ardeche. It was formally unveiled a fow days ago in the presence of a number of notabilities.

\section{An Adoress}

ox

\section{SCIENTIFIC RESEARCH IN MEDICINE \\ Delivered at the Opening of the London School of \\ Tropical Meducine.}

Bx GeORGe H. F. NU PTALL, M.A., M.D., Pн D., F.R.8.

THAT great benefits to mankind have followed the discoveries of recent years is obvious to all of us, especial'y with regard to the canses and prevention of yellow fever and malaria, and the results already obtained give abundant prumise of the good that may result from like researchrs in the future. Research is a word we hear on all sides to day. It is the enemy of mere authority-that tyrannous.8pirit which has hampered progress and retarded the advance of scinntific medicine for centuries. The spirit of research is restless of restraint; it chafes at limits ; it leads us ever onward to new questionings and new discoveries, and these in turn lead on to further inquiries. The spirit of research has come to stay. with us as long as the hope and the desire of progress in any domain of human knowledge continue to stir the minds of men.

Experimental medicine is responsible for the greatest advances which have been made in our knowledge of the cause, prevention, and cure of disease. These advances have been based on the labours of many workers, exploring often along different lines. Most important discoveries have exerted but a olight direct eff ct at their inception; their full significance has remained hidden, except perhaps to the few and far seeing. Of such discoveries the majority have been made by those engaged in research in the realms of pure science, and rarely by those guided by principles of direct and imm-diate utilit 7 . Pare science is in this respect unselfish; its aim is not prcfit, but truth ; it makes for light rather than gain. Yet it is the forerunner of that applied science which is more obtrusively the servant of man. Its guiding principle is that knowledge must be sought for its own sake, and not primarily for its. possible or probable applications. And experience has shown that new and fruit-bearing knowledge is seldom revealed to those whose sole purpose is merely utilitarian. Problems of the greatest importance to humanity are awaiting their solution at the hands of those who are willing to labour thus unselfishly, to devote themselves to science for the sake of science, and not for that of the materitl serviee which ecience can be made to yield. If we study disease, we must study disease for the sake of knowledge; the scientific spirit must enter into our work. Devotion to the study; getrated b sach motives, is certain to bring its reward, although the reward may not be material. It seems. scarcely necersary to dwell on this before an audirnce composed chiefly of men belonging to the medical profession, which of all professions is the most unselfiwh. All that can be asked is that those who devote themselves to advaneing the gcience of medicine shall bring to their work the same nuble mutives which guide the ideal physician in his effurts to alleviate the sufferings of his fellow men. The spirit of commercialism should be as foreign to the man of science as it is to the physician, for both should be idealists in the best sense of the word. The fruits of their labours may be gathered by others. but none can rob them of the joy of having brought them forth. The "practical man" may not appreciate such ideals, he may deride those who cherish them; but he is ever ready to use the discoverieg of science for his own ends. The reward of the true pioneer does not lie in what is said by "the fool multitude who choose by show"; he seeks only "the wages of going on"; he finds his recompense in delving into the wonderland of Nature with all its. hidden beauties, and thereby forgetting the smallnees that enters into all men's lives. And there is no meanness in the exultation of the esplorer when a new peak rises on his view, of the searcher of the skies "when-a new planet swims into his ken" The joy of the hunter at the kill is felt by the scirntific worker when a fact which has hitherto escaped observation rewards his patient search for truth.

Research has also its joys in the ever-changing picture that it brings before us ; the phenomena we study faseinate through their very elusiveness. We must be prepared for many disappointments and mueh labour loat; we must be ready to give up much of the ald, if we.wish to grasp the now: 